\title{
OPTIMIZING ROLE-PLAYING LEARNING STRATEGIES AND REINFORCING SELF-CONTROL TOWARD ANTI-CORRUPTION KNOWLEDGE
}

\author{
Desti Pujiati ${ }^{1)}$, Myrnawati Crie Handini ${ }^{2)}$, Moch. Asmawi ${ }^{3)}$ \\ ${ }^{1)}$ Universitas Negeri Jakarta, Jakarta, Indonesia \\ E-mail: missdestyumpp@gmail.com \\ ${ }^{2)}$ Universitas Negeri Jakarta, Jakarta, Indonesia \\ E-mail:myrnawati48@gmail.com \\ ${ }^{3)}$ Universitas Negeri Jakarta, Jakarta, Indonesia \\ E-mail: asmawi.moch@yahoo.co.id
}

\begin{abstract}
This study aimed to find out the optimizing of role-playing learning strategies and reinforcement of selfcontrol through anti-corruption knowledge in children. It is expected that through role-play children can direct their aspirations and control themselves as a basis for reinforcement in anti-corruption knowledge. The method used in this research is the $2 \times 2$ design of the experimental method. Children can develop anti-corruption knowledge so that they can adjust it to the applicable rules or norms, build self-control positively, build habits to become individuals with honesty values and courage values, be simple, build justice and work hard in the community life where children live.
\end{abstract}

Keywords: Learning Strategies; Role Playing; Self Control; Anti Corruption Knowledge

\section{INTRODUCTION}

Knowledge is formed in the structure of one's conception. Conceptual structures shape knowledge, role-playing learning constructs students' knowledge through real experience. The sharing results between friends, among groups, or with teachers can help each other exchange experiences. The application of society principle can be involved with each other; can make them learn from each other, can exchange information, and can exchange experiences. In this case, the teacher can motivate students to be like what they dream of in the future, for example, being a teacher, a soldier, traffic police, a doctor, a nurse, a farmer, a journalist, a radio broadcaster, a television broadcaster, a pilot and many others. The process of appearance is an example to make students think, learn, and play (Backley, 2012).

Learners can imitate by modeling in role-playing so that they can acquire knowledge and skills. Related to the knowledge of anti-corruption, the results of this study revealed that children can understand anti-corruption through their knowledge. Therefore, the active role of educators and participants is expected to be more focused on efforts to prevent corruption by building a culture of anticorruption actively in the community. Educators and students are expected to play roles as agents of change and become pioneers for anti-corruption movements in society. To play an active role, students need to be equipped with sufficient knowledge about the ins and outs of corruption and its eradication. Children play an active role in understanding and applying anti-corruption values in their daily lives.

Every student can assume responsibility for the progress of the nation in the future, so early childhood must get the right attention and opportunity to grow and develop optimally. Throughout the human life span, namely early childhood, the "golden period", the basis of attitudes and behavior is formed. Encouraging children is very meaningful by respecting children when expressing their opinions, by appreciating the conversation, never interrupting when children are talking, by stimulating children to observe, to question various things in their environment, by providing freedom and encouragement to fantasize, to reflect, to think, to try to realize ideas (Mulyasa, 2017). Meaningful learning begins with a game that relates to the experiences that have been possessed by students such as coordination and 
communication and meaningful relationships, collaborating, thinking critically, and creatively.

There found some Phenomena in early childhood in Banyumas district which is thought to be some factors that cause the corruption of children in the future like coming to school unpunctually, ignoring discipline, telling lies about the incident that happened to friends when crying, completing learning activities at school unpunctually (postponing the task), taking others' belongings without permission easily, overtaking the line of friends when queuing, when entering the class, or when washing hands, being reluctant to queue, buying luxurious things that are not needed but wanted by asking parents while forcing, being unhappy to see friends using new bags or shoes. Besides, adults often give bad examples when driving a car or motorcycle through traffic signs by breaking through when the lights are red. Some problems that occur can make the starting point of corruption either happened in children or adults when seen by children. Of the several problems, people are possibly tempted to commit acts of corruption because it comes from characters who are not nurtured at an early age. It affects knowledge seen when they become adults since it is a reflection of the behavior formation in early childhood. The family is expected to become an early educational institution in the implementation of anticorruption education.

According to Ciolan, Knowledge is a learning process that continues to grow. Supporting the results of Ciolan's research, (Priyowidodo \& Sari, 2017) stated that knowledge is an awareness of a phenomenon. Each individual can be measured objectively and subjectively. Objective measures emphasize that each store his/her knowledge in his/her memory. While subjective knowledge must be tracked through the memorized elements about something. Knowledge of anti-corruption as a link in the human mind to think critically between information and its application in instilling anti-corruption values (Kohlbacker, 2008). Anticorruption knowledge is to provide information through conscious and deliberate efforts to realize the critical learning process toward anti-corruption values (Hamalik, 2009).

In Bloom's Taxonomy, the knowledge domain was gained after each learning process, a learner must acquire new knowledge (cognitive, head), skills (psychomotor, hands), and attitudes (affective, heart). Anti-corruption knowledge is information about anti-corruption actions. Anti-corruption is a precautionary and preventive behavior for the development of corruption. Prevention is to increase individual awareness not to commit corruption (Syarbaini \& Arbain, 2014). Building knowledge provides a model of education to raise ideas or thoughts collectively. Knowledge is about anticorruption causes and consequences. So that students understand that taking other people's belonging without any permission is not good. Knowledge includes an understanding of how descriptive information applies to a particular context so that they can use information selectively. Information obtained is used to solve problems, so that they will have a much better life (Mathisen et al.,
2006). Anti-corruption knowledge is the understanding of anti-corruption information through a continuous learning process. (Ciolan \& Petrescu, 2014) stated that people who are very influential in the school environment are teachers. Therefore this study trained the teacher in advance so that they can teach students about anti-corruption values.

Self-control is hard to get in humans when there are no good boosters so that people easily despair. They are not developing into a human being who is more beneficial both for himself and others. This booster is very necessary for every child. Self-control is the ability of a person to control himself consciously to make such behavior that does not harm others so that it is following social norms and can be accepted by his environment (Horstkotter, 2014).

Self-control refers to the ability to compile, to guide, to regulate, and to direct the behavior that can bring individuals towards positive consequences (Goldfried \& Merbaum in Muharsih, 2008) O'Donoghue said that a child in his/ her early childhood has low self-control. The results of the study show that later on, adult children will also be associated with low behavior. People can be great, be fully aware of their future self-control problems and therefore they tend to be able to predict correctly how they will behave in the future. Individuals with low self-control are the ones who cannot control emotions, have bad behavior, and want to achieve something easily, seek sensation and adventure. Meanwhile, individuals who possess high self-control tend to be careful and to think logically.

In learning at early childhood education (PAUD), teachers and children are often faced with various problems, both in material and concerning social relations. It can be simply solved by having questions and answers between teacher and children (Besgen, Kuloglu, \& Fathaliazadehalemdari, 2015). Role-playing is an alternative strategy that can be used effectively in PAUD. Role-playing can be directed at solving simple problems involving human relationships, especially regarding children's lives in the future. Social and individual beings in their lifetime in relation with other people and the situation around them always interact to influence one another. Roles can be defined as a series of feelings, speech, and actions as unique patterns of relationships shown by individuals to other individuals. Understanding personal roles and other people are needed to play a good role. Participants, through role-playing, try to explore human relations by developing and discussing so that students can explore feelings, values of various problem-solving strategies following their respective abilities (Mulyasa, 2017). Assuming role-playing learning, students try to explore human relationships. Role-playing is rooted in personal and social dimensions. Role-playing allows students to express feelings that cannot be recognized without reflecting on others. The strategy of role-playing learning assumes that emotions and ideas can be raised to the conscious level so that it can encourage students in the group to actively participate in problem-solving while listening carefully to how other people talk about the problem at hand. The role-playing strategy then assumes that hidden psychological processes, in the form of attitudes, values, 
feelings, and belief systems, can be raised to the conscious level through a combination of spontaneous funding (Just et al, 2010).

Instilling role-playing in learning can improve learning goals with good results. When applying a suitable combination of different modern education methods, it is possible to improve the quality and attractiveness of higher education and the readiness of students, not only to complete the exam syllabus, final papers, final exams but also to deal with everyday life and work situation, creating prerequisites for the successful application of students in their activities outside of school (Ball, 2009). The last decade in the United States shows that kindergarten teachers can increase awareness in learning through role-playing, the results of early childhood research will be easier to obtain anticorruption knowledge by planting anti-corruption values.

The teacher must portray himself as a planner, observer, model, facilitator, elaborator, and evaluator. As a designer, the teacher must be able to make a lesson plan (RPP) integrated into each game (Ciolan \& Petrescu, 2014). The teacher must also able to plan new experiences so that children are encouraged to develop their interests. As an observer, the teacher must make observations on each child's activities, how interactions among children, and children's interactions with objects around them. As a model, the teacher must take part in playing activities when the students are playing so they must understand the various rules of each game. The teacher should try to be a part or model in children's play activities. As a facilitator, a teacher must be able to provide convenience to children in playing activities. The teacher must be able to explain the activities of playing or the rules of each game (Bertok \& Mesko, 2015). The teacher should a situation to encourage children to play while learning and they must also realize competency standards, basic competencies in each field of development. As an elaborator, the teacher can ask some questions that can stimulate the development of the child's thinking through the role he performs. As an evaluator, the teacher is in charge of observing and evaluating the children's playing activities so that they can meet their needs.

\section{Methodology}

This research was conducted using a quantitative approach. The method used is quasi-experimental (quasiexperimental), which is research that cannot provide complete control. In this study, the samples taken were grouped into two namely the experimental class I and the experimental class II.

The steps of role-playing (Learning Design ) are done as follows:

1. The teacher gives an example of role-playing, then the child immediately becomes a model

2. Choosing players (participants).

3. Children actively carry out the roles in the story

4. Organizing the more effective place which is wider in size

5. Prioritizing collaboration and communication among children
6. The game duration from 35 to 45 minutes.

7. Discussing role play and conducting outline evaluations by teacher and students

8. Doing second role-playing where the children were more creative and imaginative in playing roles.

9. Discussion and evaluation

10. Sharing stories of experiences by children.

\section{RESULTS AND DISCUSSION}

Knowledge of anticorruption of children with optimum self-control reinforcement by the role-playing method of groups of children who have high self-control has a score range of 0 to 15 , meaning that the highest score that can be achieved is 15 and the lowest score is 0 . The results show that the maximum score obtained is 12 and the lowest score is 8 , with an average of 10.18 , mode 11.36 median 11.50 , variance 1.56 , and standard deviation 1.25 . The frequency distribution of anti-corruption knowledge scores of children with high self-control who were given the role-playing method was classified into 4 interval classes, and each with absolute frequency and relative frequency. Overall, the frequency distribution of anti-corruption knowledge of children with high self-control who have given the roleplaying method.

This research is proven by the results of data emphasis that the knowledge of anti-corruption students with high self-control through role-playing is better than students with low self-control. This is evidenced by the average score of anti-corruption knowledge shown during the learning process. The role-playing method is a game that provides important experiences that support the acquisition of cognition, social, emotional, and language knowledge and skills, that is performed by imagining themselves into the future and re-creating past conditions (Wycliffe, 2013). Role-playing has advantages, namely: (1) It can generate motivation, interest, or passion for student learning, (2) It can stimulate students' desire to learn more, (3) It can provide opportunities for students to give their responses to the material presented, (4) Can guarantee the development of student personality activities, (5) It can educate students in self-learning techniques and how to obtain knowledge through personal business, (6) It can instill and develop student values and attitudes in daily life.

Research in Journal Sage (Westrup \& Planander, 2013) states that role play supports children in gaining insight, into leadership situations. Role-playing activities involve human resource management problems that are designed, carried out, and evaluated as part of a management program. The results show that role-playing can stimulate children to understand problems from a variety of perspectives, to make changes to the overall perspective. Active social interaction and role-playing conversations contribute to building a sense of togetherness. We argue that role play can be a viable and powerful learning strategy where the teacher allows their students to prepare for training. Children with high selfcontrol tend to have high anti-corruption knowledge too. This is because children with high self-control will be able to refrain from doing abnormal attitudes (corruption). After all, 
they know the good and bad consequences of their deeds. This is in line with the opinion of Meltzer et al. (2013) that the reinforcement of self-control is the ability to stop and think before acting. Emotional control is the ability to regulate feelings by thinking about the goals to be achieved (Meltezert, 2013). Bertok and Mesko explained that individuals with low self-control cannot control emotions, have bad behavior, and are eager to achieve things easily, seek sensation, adventure, while individuals who possess high self-control tend to be careful and think logically (Bertok \& Mesko, 2015).

According to the theory of self-control factors (the ability to execute mental control over one's behavior) and default responses. Previous research has shown that self-control has a broad effect on social behavior and decision making. The results of Evan show that the effect of self-control on trust depends on default. Self-control affects trust indirectly by influencing the level of effort in decision making.

Based on the results, Children will understand the values of anti-corruption better by modeling independently, so the role-playing method tends to be successful, especially supported by high self-control in their childhood. The findings in this study show that the use of role-playing methods is more effective in increasing students' anticorruption knowledge for children with high self-control.

\section{CONCLUSIONS}

Based on the results of the average empirical data in the field, it can be assumed that, when playing a role is used in early childhood in this case for prevention of corruption, the child will indirectly know which ones to do and which ones to avoid. Building knowledge of child anti-corruption becomes important because it becomes provision at an early age and can prevent from corruption act that has been grounded so that children are expected to be able to apply the principles of the clean and good life, as well as the use of transparency in the future.

\section{REFERENCES}

Backley, Part. (2012). Learning in Early Childhood, A Whole Child Approach From Brith to 8. SAGE, 152.

Ball, D.L, \& Forzani, F.M. (2009). The work of teaching and the challenge for teacher education. Journal teacher Education, $\quad 60(5)$, https://doi.org/10.1109/MIE.2011.940249

Bertok, Eva \& Mesko, Gorazd. (2015). Self Control and Morality in Slovenian Primary and secondary school sample: The Results of yuoPrev Study. Journal: Criminal Justice and Security, 15(4), 482.
Besgen, A., Kuloglu, N.\& Fathaliazadehalemdari, S. (2015). Teaching \& Learning Strategy Thought Art: Art and Basic Design Education. Procedia-Social and Behavioral Sciences, 182, 428-432. https://doiorg/10.1016/j.sbspro.2015.04.813

Ciolan, Laura \& Petrescu, Anca. (2014). Training Teachers to use Digital Resources for the Knowledge Society. Procedia-Social and Behavior Science 128, 415-419

Hamalik, Oemar. (2009). Kurikulum dan Pembelajaran. Jakarta: Bumi Aksara.

Harald, Mathisen, Nick Duncan, et al. (2006). Knowledge Management for Anti-Corruption: Problems. Perspectives and Prospects (Summary Note with Peer Review) Summary Note: Harald Mathisen and Nick Duncan (based on study by Bryane Michael) U4 ISSUE: 2:200

Horstkotter, Dorothee. (2014). Self-control and normativity: Theories in social psychology revisited. Journal Sage Theory \& Psychology, 25(1), 25-44. First Published December 1, 2014.

Kohlbacker. (2008). Knowledge-based New Product Development: Fostering Innovation Through Knowledge Co-creation. International Jurnal of Technoloy Intelegence and Planning, 4(3), 358.

Meltzer, Lynn., Greschler, Michael., Krishnan, Kalyani et al. (2013). e-book: Executive Function 101 (National Center for Learning Disabilities). www.LD.org (Accessed November 3, 2016).

Mulyasa. H. E. (2017). Strategi Pembelajaran PAUD. Bandung: PT. Remaja Rosdakarya.

Priyowidodo, Gatut \& Sari, Yustisia Ditya. (2017). Model Komunikasi Dan Strategi Kebijakan Kesadaran Anti Korupsi Melalui Pendekatan Character Building Berbasis Literasi Media. Yogyakarta: Andi. p.13.

Syarbaini, Amirullah \& Arbain, Muhamad. (2014). Pendidikan AntiKorupsi: Konsep, strategi, dan implementasi pendidikan anti korupsi di sekolah/madrasah. Bandung: Alfabeta. p.6.

Westrup, Ulrika \& Planander, och Agneta. (2013). Role-play as a pedagogical method to prepare students for practice: The students' voice. http://hogreutbilding.se/index.php/hu/article/view/801 $/ 1744$

Wycliffe, Amukowa. (2013). The Role of Anti-Corruption Education in the Light of Aristotelian Concept of Akrasia: An Epistemic Inquiry into the Anticorruption Initiatives in Kenya. Mediterranean Journal of Social Sciences, 4(4). 